\title{
最近の技術と研究から
}

\section{電子ビーム加熱を用いたガス蒸発法による 高融点物質の超微粒子の生成とその焼結”}

\author{
岩 間 三郎** 浅 田千 秋**
}

Key words: electron beam heating, gas evaporation technique, high melting point material, ultrafine particles, nitride, sintering.

\section{1. は じめに}

上田らによって開発された「ガス蒸発法」1) は低圧の ガス雾囲気中で物質を蒸発させてその超微粒子を生成す るものであり，この方法によって作られた多くの金属超 微粒子の形態, 結晶構造等は詳しく調べられている2). この方法の一つの特長は䨌团気ガスの種類, 圧力および 蒸発源の温度を制御することにより, 粒径数 $\mathrm{nm}$ から数 百 $\mathrm{nm}$ の範囲である程度の粒径制御ができる点である. また得られる粒子の表面は他の方法で作られるものに比 べて極めて清浄である.この方法によってすでに幾種類 かの金属超微粒子の生産が工業的規模で行われ，その利 用実績も報告されているのに比べ3），高融点物質（単体 金属および化合物) の超微粒子のそれはかなり遅れてい る. それは高温度の加熱を可能にする熱源が得難いこと による．乙かし高融点金属の超微粒子に対しては, 超伝 導材料における高抗磁力をはじめ4）多くの優れた性質に 期待がもたれている．最近, $\mathrm{CO}_{2}$ レーザ, 通電加熱等の 熱源を用いて炭化物, 窒化物および酸化物の超微粒子の 生成が行われている5) 8). その一つのねらいは，一般に 高融点かつ難焼結性であるこれら化合物を超微粒子化す ることにより，その焼結性の向上を図ることにあるが， 更にそれによって焼結体の質の向上も期待される。また ガスセンサに利用された $\mathrm{SnO}_{2}$ 超微粒子8) の例に見るよ らに，新しい機能材としての用途の開発は化合物，合金， 単体金属の超微粒子全般にわたって広く進められてい る3).

筆者らは電子ビーム加熱を用いたガス蒸発法によっ て, 高融点物質を除く幾種類かの金属超微粒子の生成を 行った9). その後, 電子ビーム容量の増大を図るととも に高融点物質の超微粒子の生成を試みた。抵抗加熱法に よっても Wをはじめとする高融点金属の超微粒子の生 成は可能であるが10), 粉の量産には不利である.ここで は筆者らの方法を紹介し, それによって得た 4 種類の単 体金属の超微粒子 ( $\mathrm{W}, \mathrm{Mo}, \mathrm{Ta}, \mathrm{Nb})$ と 2 種類の 窒化物

* 原稿受付 昭和 56 年 9 月 24 日.

** 大同工業大学 (名古屋市南区大同町 2-21)
超微粒子 ( TiN, AlN) の電顕観察を中心に報告する. 単 体金属の超微粒子についてはその焼結実験もあわせて報 告する.

\section{2. 電子ビーム加熱を用いたガス蒸発法}

図 1 に装置の模式図を示す。装置は電子銃, 電磁レン ズ等からなる電子ビーム照射系と, 材料の蒸発が行われ る蒸発槽とから成る。電子銃部と蒸発槽は三つのオリフ ィスで継がれ，各部は真空ポンプに接続されている. あ らかじめ装置内を油拡散ポンプで 10-5 Torr 以下の圧力 に排気した後に, 蒸発槽の主バルブ $\mathrm{V}_{1}$ を閉じ, ガス導入 口を通して雾囲気ガスを導入する．との後にバルブ $\mathrm{V}_{2}$ を開け，蒸発槽は油回転ポンプで排気されて 約 1 Torr のガス圧に保たれる．最終段オリフィスの下方部から噴 射されたガスはその大半が蒸発槽へ流れ, 微粒子の生成 時に必要な雲团気ガスとして働く，照射系へ流れた一部 のガスは図示した差圧排気系によって排気されて電子銃 部の高真空が保たれる。このようなガス導入法は生成さ れた粒子の電子銃部への逸散を防ぎ，電子銃部の污れを 極めて少なくする，その結果長時間の連続稼動が可能々 なった。

被蒸発物質の違いによって次の 2 通りの方法で蒸発が 行われた. (1) 線材（直径 $0.2 \mathrm{~mm}$ 程度）を連続的に電子 ビーム中へ送り込み, その先端から蒸発させる. (2) 塊材

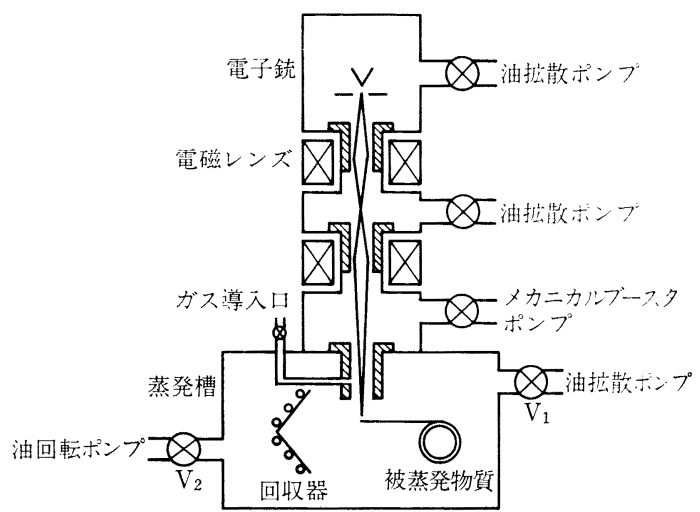

図 1 電子ビーム加熱を用いたガス蒸発装置 


\begin{tabular}{|c|c|c|}
\hline 材 & 料 & 純度 $(\%)$ \\
\hline \multicolumn{2}{|c|}{$\mathrm{Ar}, \mathrm{N}_{2}$} & 99.999 \\
\hline \multicolumn{2}{|c|}{$\mathrm{W}, \mathrm{Ta}, \mathrm{Al}, \mathrm{NH}_{3}$} & 99.99 \\
\hline \multicolumn{2}{|c|}{$\mathrm{Mo}, \mathrm{Nb}$} & 99.95 \\
\hline \multicolumn{2}{|c|}{$\mathrm{Ti}$} & 99.9 \\
\hline
\end{tabular}

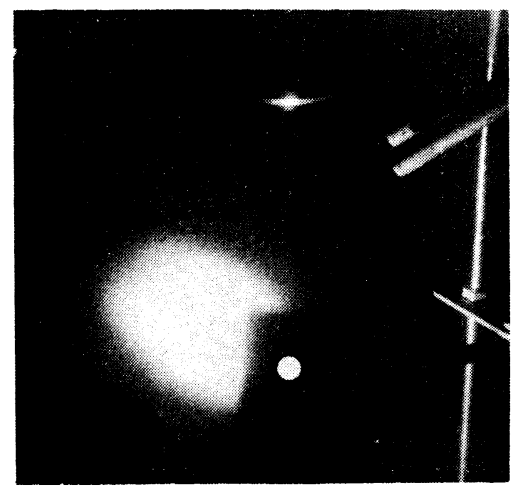

白丸は蒸発源の位置

図 $2 \mathrm{~N}_{2}$ ガス 1 Torr 中で Ti を蒸発させている写真

を炭素ルッボ中に支持して蒸発させる. W, Mo, Ta, Nb および Ti に対しては (1) の方法が，他方 Al と対しては (2)の方法がとられた. (1)の方法では被蒸発物質のみが 加熱されることでルッボを使用した時にしばしば起こ る被蒸発物質とルツボ材との化学反応，およびルツボ材 の蒸発汇起因する不純物の混入を避けることができる. またルツボへの熱の逃げが無いことによって (1)の方法 は (2) に比べてょり高温の加熱が可能である. 電子ビー ムが鉛直方向をとる本装置では, 熱伝導率が高く, かつ 高温強度の劣る $\mathrm{Al}$ の場合, 電子ビーム照射によって線 材が垂れ下がるため (1)の方法は使えない。

加熱蒸発された物質は雾囲気ガス中で泠却・凝結を繰 り返して超微粒子を形成し, 冷却された回収器に付着す る. 単体金属の超微粒子を生成するためには Ar ガスが, 一方窒化物超微粒子を生成するためには $\mathrm{N}_{2}$ なたは $\mathrm{NH}_{3}$ ガスが雾囲気ガスとして使われた，用いた材料の純度を 表 1 以示す。電子ビームのパワーは $0.2 \sim 1 \mathrm{~kW}$ の範团 であった．図 2 に $\mathrm{N}_{2}$ ガス中で $\mathrm{Ti}$ を蒸発させている時 の写真を示す．蒸発源の囲りに見られる生成粒子の作る 煙が左方に流れているのは, 雾囲気ガスが左方から排気 されているためである. 煙の流れている側汇置いた回収 器からは蒸発量の約 8 割が超微粒子として回収される. 1 Torr 程の低圧中に括いても比較的容易にガスの流れ を利用して生成粒子の回収効率を高めることができた。

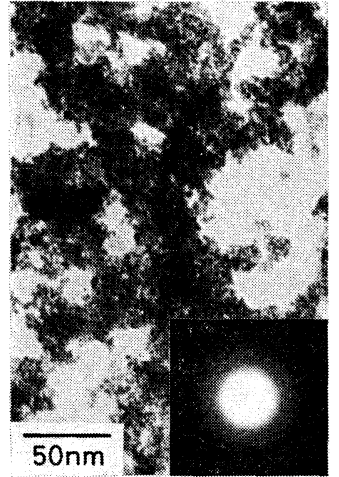

(a) $\mathrm{W}$ 超微粒子

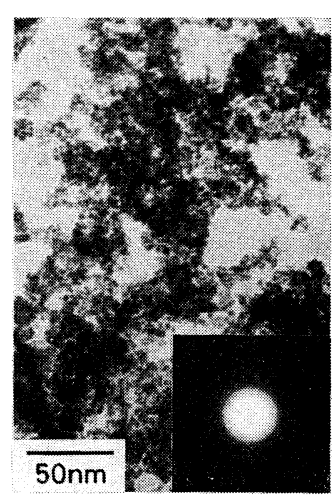

（b） Mo 超微粒子
図 $3 \mathrm{~W}$ および Mo 超微粒子の電顕写真と電子線回折 パターン

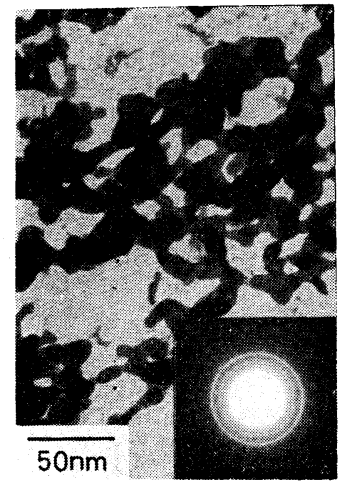

加熱は $800^{\circ} \mathrm{C}, 3 \mathrm{~min}$

図 4 高真空中で加熱した $\mathrm{W}$ 超微粒子の電顕写真と その電子線回折パターン

\section{W, Mo, Ta, Nb 超微粒子およびその焼結}

$\mathrm{Ar}$ ガス中で W, Mo を蒸発させて得られた超微粒子 の電顕写真を図 3 (a), (b) 示市. 粒径は共飞約 $5 \mathrm{~nm}$ である。これらの粒子の電子線回折パターンが八ローに 近いのは粒径が極めて小さいためと考号られる.抵抗加 熱によって作られた粒径数十 $\mathrm{nm}$ の W, Mo の超微粒子 には A-15 型構造をとるものが報告されているが10)，図 3 の回折パターンからは明確な結晶構造の 解析は困難で ある.

これらの超微粒子を高真空中 $\left(3 \times 10^{-6}\right.$ Torr $)$ で加熱 すると次の結果が得られた. W の場合, 約 $700^{\circ} \mathrm{C}$ で通常 の体心立方構造を示す回折線に加えて $\mathrm{WO}_{2}$ の 回折線が 現れる．更に高温に加熱すると $\mathrm{WO}_{2}$ の 回折線強度は弱 まり，約 $800^{\circ} \mathrm{C}$ では体心立方構造のみの明りょうな回折 線となる，その電顕写真には顕著な融合成長の跡が観察 される（図 4). 加熱汇よって粒子表面は酸化されるが， 揮発性の $\mathrm{WO}_{2}$ はほほぼ $800^{\circ} \mathrm{C}$ の加熱沉よって昇華し，そ 


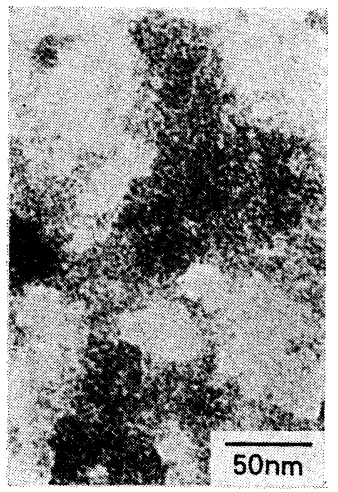

(a) Ta 超微粒子

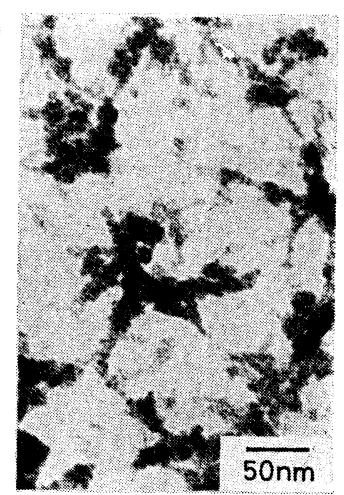

(b) $\mathrm{Nb}$ 超微粒子
図 $5 \mathrm{Ta}$ および $\mathrm{Nb}$ 超微粒子の電顕写真

の結果粒子同志の融合成長が起こりやすくなり焼結が進 行したものと考兄られる. Mo の場合にも W と同様な傾

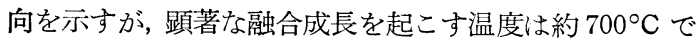
あった.これらから本方法で生成した粒径約 $5 \mathrm{~nm} の W$, Mo 超微粒子は融点の $1 / 4$ ～1/3 の温度で顕著な 焼結を 開始することがわかる.

$\mathrm{Ta}$ 预よび $\mathrm{Nb} \mathrm{Ar}$ ガス中で蒸発させた場合にも粒 径約 $5 \mathrm{~nm}$ の超微粒子が得られる（図 5)，それらの電子 線回折怾ローパターンを示した。これらを高真空中で 加熱すると約 $800^{\circ} \mathrm{C}$ でそれぞれ $\mathrm{Ta}_{2} \mathrm{O}_{5}, \mathrm{NbO}_{2}$ の回折線 が現れ， $1000^{\circ} \mathrm{C}$ まで加熱ではそれら酸化物の粒成長 が見られた、両酸化物はこの温度範囲で安定であるた め11) W, Mo 超微粒子とは異なる焼結性を示す.

熱処理を施していない上記 4 種類の金属超微粒子の電 子線回折が散漫なパターンを示したことの要因の一つに 粒子の表面酸化の影響が考兄られる. 生成粒子は電顕観 察までの間に少なからず表面酸化を受けると考えられ る. そのため芯の金属結晶部は見かけの䊀子径上り更に 小さくなり，サイズ効果による回折線の広がりは強調さ れる.しかしそれらの電子線回折バターンに明りょうな 酸化物の回折線が見ら机ないことから，この場合表面酸 化層は微細な結晶粒の集まりか，あるいは非晶質状態之 考えられる. 生成粒子が非晶質の金属超貒粒子から成る 場合にも回折線はハローバターンとなるが，今回の実験 結果だけからそれを断定することはできない。

\section{TiN, AlN 超微粒子}

$\mathrm{N}_{2}$ ガス中で $\mathrm{Ti}$ を蒸発させると粒径 $10 \mathrm{~nm}$ 以下の超 微粒子が得られる。これらの粒子には立方体の晶癖をも つものが多く観察される(図 6). 電子線回折パターンか らこれらは $\mathrm{NaCl}$ 型構造の TiN であることがわかる. $\mathrm{NH}_{3}$ ガス中でTi

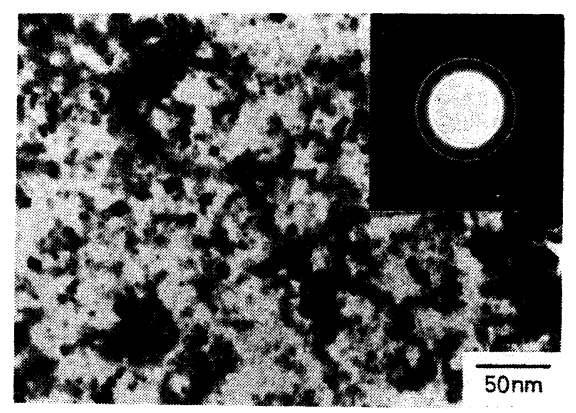

図 $6 \mathrm{TiN}$ 超微粒子の電顕写真と電子線回折パターン

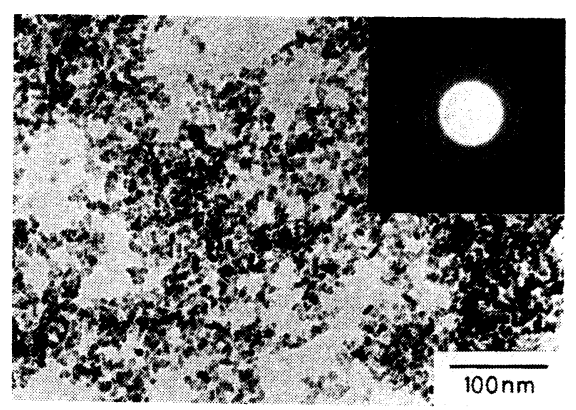

図 $7 \mathrm{~A} 1 \mathrm{~N}$ 超微粒子の電顕写真と電子線回折パターン

生成されるが, 同じガス圧の $\mathrm{N}_{2}$ ガス中の蒸発で得られ る粒子より一般に粒径が小さい，生成され心超微䊀子の $\mathrm{X}$ 線回折には TiN 以外の回折線は認如机なかった。

$\mathrm{NH}_{3}$ ガス中で $\mathrm{Al}$ を繁発させるとウルツ型構造をもこ 粒径約 $8 \mathrm{~nm}$ の AlN 超微䊀子が得られる（図 7). しか し $\mathrm{N}_{2}$ ガス中で $\mathrm{Al}$ を蒸発させた場合には $\mathrm{AlN}$ 超微粒子 は生成されず， $\mathrm{Al}$ 超微粒子を得るのみである。・Ti の場 合と異なり，この場合の $\mathrm{N}_{2}$ ガスは $\mathrm{Al}$ に対して不活性 であることがわかる。

\section{5. 超微粒子の生成量と被蒸発材料の線径との関係}

図 8 は Ar ガス中で W を蒸発させた時の, 用いたW 線の径注対して蒸発量を表したものである。この場合一 定なパワーの電子ビームは約 $1 \mathrm{~mm}$ の太さ洨られてお り, 線材の先端にできる溶けた玉の径が約 $1 \mathrm{~mm}$ を保つ ように線材の送り込みが調節された。この図から線径が 小さい程蒸発量の多いことが示される。蒸発量が線径の 二乗の逆数に比例することは, 伝導によって線材の先端 から根元へ向かって逃げる熱量の違いが蒸発量の違いに 反映されるためと考觉られる。

$\mathrm{N}_{2}$ ガス案たは $\mathrm{NH}_{3}$ ガス中で $\mathrm{Ti}$ 線を蒸発させた場合， Ar ガス中の蒸発と異なり, 線材の先端は玉にならず針 状となる．X 線回折はこの針状部が TiNであることを 示し, Ti は蒸発に先立って窒化されることがわかった. Tiに比べて蒸気圧の低いTiN が形成されるが，先端部 


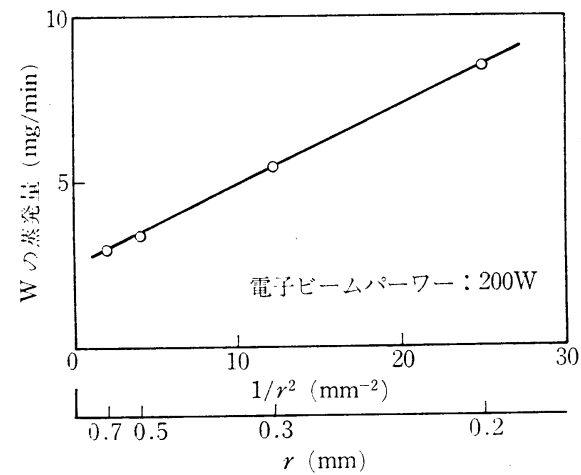

図 8 笔子ビーム湿射される W 線の径 $\boldsymbol{r}$ に対する蒸発量の関係

が針状の形をとることは蒸発面積を広くする点で都合が 良い. 先汇㐫げた図 2 は直径 $0.2 \mathrm{~mm}$ の $\mathrm{Ti}$ 線を 50 本束 ねて電子ビーム照射している時の写真であるが, 同じ断 面積をもつ $\mathrm{Ti}$ 棒 1 本でこの写真に見るような煙が生じ る程の蒸発量を得ることは困難である. 以上の結果から， 線材の先端を電子ビーム照射して加熱蒸発させる場合, 用いる線材の径が小さい程単位時間当たりの超微粒子生 成量は多くなることがわかる。

\section{6. おわりに}

電子ビーム加熱は高エネルギー密度を得るのに適した 加熱手段の一つである. 本稿で紹介したように，これを ガス蒸発法の熱源に用いることにより幾つかの高融点物 質の超微粒子を生成することができる。また得られた超 微粒子はかなり低い温度で燒結することが一部の試料で 示された，本装置の電子ビームの容量は実験室的規模の ものであり, 得られる超微粒子の量（例えば TiN の場 合, $30 \mathrm{mg} / \mathrm{min}$ ) は小規模な粉の応用研究に供し得る程 度で方る. 生成量の大幅な増加には電子ビームの容量の 增大が必要である。

本方法で生成された高融点物質の超微粒子はすべて粒 径が $10 \mathrm{~nm}$ 以下であった。 これは雾团気ガスの圧力が通 常のガス繁発法でとられている值に比べて低いこと，お よび被蒸発物質の融点が高いことによると考兄られる $\left(\mathrm{NH}_{3}\right.$ 分ス中で $\mathrm{Al}$ を蒸発させる場合, $\mathrm{Al}$ の窒化 $\rightarrow \mathrm{AlN}$ の蒸発之考えられる実験結果を得ている12)). 粒径が 10 $\mathrm{nm}$ を切る超微粒子を生成する方法に 流動油面上真空蒸 着法がある13)14)。これは油中に超微粒子を得るものであ るが，本稿で述べた方法はガス蒸発法を用いているので
通常の粉末状の超微粒子を得る点がそれと異なる。

蒸発時の䨌团気ガスの種類を变えることにより, 本方 法は上述した単体金属, 窒化物以外に, 酸化物, 炭化物 の超微粒子生成にも適用できると思われる。

この研究の全般にわたって名古屋大学工学部美浜和弘 教授, 本学有住徹弥教授並びに高木豊教授から熱心な御 指導と激励を賜った. 大同特殊鋼(株)研究開発本部長澤 繁樹氏，同機械事業部副事業部長江口勇氏には種々の御 便宜を図っていただいた。また本学早川謙二助手には実 験の多くで協力を得た．これらの諸氏に対してここに深 く感謝の意を表します。

\section{文献}

1) R. Uyeda: Growth of Polyhedral Metal Crystals in Inactive Gas, J. Cryst. Growth, 45, (1978) 485.

2) K. Kimoto: Small Metallic Particles Produced by Evaporation in Inert Gas at Low Pressure, 日本結晶 成長学会誌, 6 (1979) 122.

3）賀集誠一郎：金属超微粉，進められている用途開発，金 属, 49 (1979) 31.

4) 小田正明, 田崎 明: 超微粒子材料, 電子通信学会誌, 63 (1980) 395.

5）和田伸彦：化合物超徽粒子，応用物理，50（1981） 151.

6) 安藤義則：炭化物超微粒子, 応用物理, 50 (1981) 153.

7) K. Yamauchi, S. Yatsuya and K. Mihama: Growth of Fine Particles of the $\mathrm{Fe}-\mathrm{N}$ System Prepared by Reactive Gas Evaporation Technique, J. Cryst. Growth, 46, (1979) 615.

8）阿部 惊, 小川久仁, 西川雅博: 集積化超微粒子ガスセ ンサ, Nat. Tech. Rep., 26, (1980) 457.

9) S. Iwama, E. Shichi and T. Sahashi: Preparation of Fine Particles by Gas Evaporation Technique with Electron Beam Heating, Japan. J. Appl. Phys., 12, (1973) 1531.

10) Y.Saito, K. Mihama and R. Uyeda: Formation of Ultrafine Metal Particles by Gas-evaporation VI, Bcc Metals, Fe, V, Nb, Ta, Cr, Mo and W, Japan. J. Appl. Phys., 19, (1980) 1603.

11）寺尾宣三： $\mathrm{Nb}, \mathrm{Ta}$ 酸化物の構造，日本金属学会報， 8 (1969) 509.

12) S. Iwama, K. Hayakawa and T. Arizumi: Ultrafine Powders of TiN and AlN Produced by a Reactive Gas Evaporation Technique with Electron Beam Heating, J. Cryst. Growth, 56, (1982).

13) S. Yatsuya, K. Mihama and R. Uyeda: A New Technique for Preparation of Extremely Fine Metal Particles, Japan. J. Appl. Phys., 13, (1974) 749.

14）松岡是治, 森永 洋：流動油面上真空蒸着法による銀微 粒子の作製, 応用物理, 49 (1980) 250 . 